\title{
Growth Performance and Marketing of Maize in Karnataka, India
}

\author{
Murulidhar M. Venkannanvara ${ }^{1 *}$, G. M. Gaddi ${ }^{2}$ and C. P. Gracy ${ }^{3}$ \\ ${ }^{1}$ Department of ABM, UAS, Dharwad, India \\ ${ }^{2}$ Department of Agriculture Economics, UAS, Bengaluru, India \\ ${ }^{3}$ Department of Agricultural Marketing, Cooperation and Agribusiness Management, \\ $U A S$, Bengaluru, India \\ *Corresponding author
}

\section{A B S T R A C T}

Keywords

Carbohydrate, Starch, Fiber and protein

\section{Article Info}

Accepted: 04 September 2019 Available Online: 10 October 2019
Maize (Zea mays) is one of the important cereal crops of the World and gaining lot of importance in animal feed and other industry uses. The present study aimed at assessing the growth performance maize and efficiency of identified marketing channels in major APMC's for maize of Karnataka viz. Davanagere, Haveri and Hassan of the Karnataka state. The secondary data on maize area, production and yield collected for fifteen years from 1990-91. The primary data were collected from 60 maize growing farmers, 15 commission agents, 15 village merchant / traders in equal proportion operating in three selected APMCs using random sampling technique. The results of the study revealed two major marketing channels for maize. The Channel-I was practiced by 66.66 per cent of the respondents and Channel-II adopted by 33.33 per cent of the respondents. In the total price spread, share of marketing cost and profit margins of various intermediaries was 75 per cent and 25 per cent in channel -I, while the respective figures for channel-II were 80 per cent and 20 per cent. The producer's share in consumer's rupees was relatively more in channel -II (86.6\%) compared to channel -I (83.7\%). Thus, Channel-I was found to be relatively more efficient than Channel -II.

\section{Introduction}

Maize (Zea mays) is one of the important cereal crops of the world. Maize is a rich source of carbohydrate, starch, fiber and protein for humans and animal dietary requirements. It also serves as a basic raw material in the production of starch, oil and protein, alcoholic beverages, food sweeteners and fuel which is cheaper than other cereals. It is also a versatile crop, grown across a range of Agro Ecological Zones in India. The global area and production of maize during 201617was 186 million ha and 1075.2 million MT, respectively. Even though India being the fifth largest producer of maize in the world but 
contributes for only about four per cent of the global production, since USA and China together accounts for more than 75 per cent of the global production. Although, maize is grown throughout the year, about 90 per cent of the India's production comes from kharif crop.

Price received for the farm produce by the farmers depends upon and intern indicates the efficiency of marketing channels. The efficiency of marketing channels has an important role in the farm income and nation's economy, as prices of farm products affects the production decisions of the farmers and their income. However, there exists wide fluctuations in prices of farm commodities, which is a big challenge that agriculture sector is facing. This can be mainly attributable to dependence of farm production on monsoon including many unforeseen factors and importantly the involvement of market middlemen. The prices of farm products also have the profound influence on the decisions in industrial sector and consumers. The trend in the farm commodity prices give signals for making judgment on policy formulation and executive action in the sphere of economic activities.

In the short run, farmers make use of information on output prices to determine the pace and volume of his sales so as to optimize the return from farm production, while in the long run, knowledge of price trends help farmer to formulate the investment plan on his farm and to take decisions on the composition and nature of enterprises to be taken up.

Knowledge of prices onfarm products and costs help farmer to react logically to the marketing situations to have proper marketing plan for his products and purchase of his required inputs. The production plans of any farmers are governed by the price expectations of proposed commodities and these expectations are based on the trends in prices of both output and agricultural inputs.

For the farmer, disposal of the farm produce at remunerative prices has become as important as an adoption of new technology for improving yields in agriculture. The pattern of movement of the produce from farm to the ultimate consumer plays a crucial role in determining the returns to the farmers. Unless the marketing system improves, any policies directed towards bringing improvements in production will not benefit the farmer in reaching the desired results. Better returns, stable price and attractive terms of trade will induce the farmers to produce more and market. In this context, appropriate market system, its growth and efficiency is crucial.

Organized marketing of agricultural commodities has been promoted in the country through a network of regulated markets. These regulated markets were established as per the provisions of the Marketing of Agricultural Produce Acts' of respective State Governments. The basic objective of networking of markets is for the development of market structure to fetch remunerative prices to the producer through fair play of supply and demand forces including narrowing of the price spread in marketing. It also aims to regulate market practices, attain transparency in transactions for better prices of farmers. In the this background the present study was undertaken with an overall objectives of studying the growth performance of maize in Karnataka and study the efficiency of existing marketing channels for maize.

\section{Materials and Methods}

\section{Nature and source of data}

The study was based on both the secondary and primary data. The secondary data on area, production and productivity of maize were 
collected from the Directorate of Economics and Statistics, Government of Karnataka for the period from 1990-91 to 2014-15. The primary data related to maize marketing like cost incurred, price realised and profit margins for estimation of price spread were collected from farmer, trader respondents operating in three major markets in Karnataka viz. Davanagere, Hassan and Haveri. The primary data on details of marketing were collected by personal interview method from 60 maize growing farmers, 15 commission agents, 15 village merchant / traders in equal proportion operating in three selected sample APMCs for the study using the random sampling technique using pre-tested well structured schedules.

\section{Analytical tools}

The compound growth in area, production and productivity of maize were estimated using following form of an exponential form of the function.

$Y=a b^{t} e^{u}$

Where, $\mathrm{Y}$ is Dependent variable (area/production/productivity), a is Intercept, b is Regression coefficient, $\mathrm{t}$ denotes Time period in years and $\mathrm{e}^{\mathrm{u}}$ is the error term

In the logarithmic form the function is expressed as,

$\log \mathrm{Y}=\log \mathrm{a}+\mathrm{t} \log \mathrm{b}+\mathrm{u}$

$\log a$ and $\log b$ were obtained using the Ordinary Least Squares (OLS) procedures. The Compound annual growth rate (g) was then computed using

$g=(b-1) * 100$

Where, $\mathrm{g}$ is the compound annual growth rate $(\%)$ and ' $r$ ' is the antilog of $\log b$.
The significance of the CAGR was tested using ' $\mathrm{t}$ ' test. The primary data on marketing were used to estimate the price spread in various marketing channel using measures of central tendency like simple averages and percentages for meaningful interpretation.

\section{Results and Discussion}

\section{Growth performance of Maize in Karnataka}

Timely and upto date information on area, production and yield level of crops is useful for making any farm policy. The growth rates in area, production and yield of Maize in major districts and for the Karnataka state were worked out for fifteen years period from 1990-91and results are presented Table 1.

It could be observed from the table that the maize production in the state during the study period increased at 7.76 per cent per annum. This significant growth rate in Maize production of the state was due to area expansion. State exhibited significant growth rate of 8.02 per cent per annum in area under Maize. However, state has registered a marginal decrease in the Maize productivity ($0.25 \%)$.

The district-wise contribution and analysis of growth performance of Maize in Karnataka revealed that Davanagere, Haveri, Belagavi, Chitradurga, and Bellary together accounted for about 50 per cent of area and production of Maize in Karnataka. The production of Maize registered significant growth rate in most of the major maize cultivating districts.

The highest growth rate in production was observed in Chikamagaluru district $(22.49 \%)$ followed by Chikaballapur (16.37\%) and Hassan (16.24\%) and growth rates were highly significant at one per cent. The major maize cultivating districts viz., Davanagere, 
Haveri, Belagavi and Bellary registered higher growth rates and growth rates were significant at one per cent. While, Chitradurga and Bijapur districts being other important districts showed positive growth rates in area but due to negative growth rates in productivity, the production growth rates were turned out to be non-significant.

The district-wise growth rates in Maize area revealed that again Chikkamagaluru registered the highest growth rate $(22.85 \%)$ followed by Hassan (15.82\%) Chikkaballapur (13.72\%) Koppal (13.49\%) and Tumakuru (11.26\%) and growth rates of Maize area in these districts found to the significant at one per cent probability level.

The growth rate of Maize productivity in all the major districts positive but not significant, while it was negative and significant in Chitradurga (-2.71\%) and Bellary (-1.79\%) districts.

This may be attributable growing of Maize on marginal lands and most uncertain rainfall patterns. The productivity of maize was higher than the state average productivity in Belagavi, Bijapur and Bagalkot districts.

In rest of the major maize growing districts the productivity was lower than the state average.

Thus growth in the Maize production in the state was area lead growth and productivity found to be remained stagnant. This could be attributable to non-adoption of all the recommended package of practices by the farmers and most of the varieties or hybrids reached their maximum yield plateau. Thus it calls for more concerted efforts towards research in breeding and release of HYV's and hybrids by both the SAU's and Companies coupled with strong extension service to educate farmers to boost maize productivity and meet increasing demand for maize.

\section{Marketing of maize}

Marketing channels denote the routes through which the producer-sellers dispose-off their produce. The price spread is one of the important measures of marketing efficiency which indicates the producer's share in consumer rupee. It includes marketing cost incurred at various levels in the movement of maize produce from the (farmer) producer to consumer as well as marketing margin that the intermediaries receive for their services in moving the maize through various stages in the marketing channels. The difference between the price paid by the consumer and the price received by the producer for an equivalent product constituted the marketing cost and the margin.

In the study area, farmers found selling their produce through four marketing channels. Among the four channels, due to insufficiency of the minimum required sample only Channel-I and Channel-II were considered for estimating the marketing efficiency. They include

Channel I: $\quad$ Producer $\rightarrow$ Village trader $\rightarrow$ wholesaler cum commission agent $\rightarrow$ Retailer $\rightarrow$ Consumer

Channel II: $\quad$ Producer $\rightarrow$ wholesaler cum commission agent $\rightarrow$ Retailer $\rightarrow$ Consumer

The Channel-I was practiced by 66.66 per cent of the respondents and Channel-II adopted by 33.33 per cent of the respondents. The other two channels noticed in the study area include Channel-III (Direct selling to consumers) and Channel-IV (Direct selling to Feed Manufacturing Units) which were not practiced widely. It was also observed during the survey that some of the farmers adopted more than one marketing channel for maize sale. 
Table.1 Growth performance of Maize in Karnataka during 1990-2014

(Area in Ha, Production in tones and Productivity in Kgs/ha)

\begin{tabular}{|c|c|c|c|c|c|c|c|c|c|c|}
\hline \multirow[t]{2}{*}{ Sl.No. } & \multirow[t]{2}{*}{ Particulars } & \multicolumn{3}{|c|}{ Area } & \multicolumn{3}{|c|}{ Production } & \multicolumn{3}{|c|}{ Productivity } \\
\hline & & TE 2014 & $\begin{array}{c}\% \text { to } \\
\text { the } \\
\text { State }\end{array}$ & CAGR (\%) & TE 2014 & $\begin{array}{c}\% \text { to } \\
\text { the } \\
\text { State }\end{array}$ & $\begin{array}{c}\text { CAGR } \\
(\%)\end{array}$ & $\begin{array}{c}\text { TE } \\
2014\end{array}$ & $\begin{array}{c}\text { Change } \\
\text { over } \\
\text { state } \\
\text { Average }\end{array}$ & $\begin{array}{c}\text { CAGR } \\
(\%)\end{array}$ \\
\hline 1. & Davanagere@ & 181957 & 13.43 & $3.66 * * *$ & 527886 & 13.83 & $5.30 * * *$ & 3052 & 3.11 & $1.59^{\mathrm{NS}}$ \\
\hline 2. & Haveri@ & 156449 & 11.55 & $6.10 * * *$ & 411678 & 10.79 & $5.70 * * *$ & 2837 & -4.17 & $-0.38^{\mathrm{NS}}$ \\
\hline 3. & Belagavi & 146335 & 10.80 & $3.69 * * *$ & 497545 & 13.04 & $4.41 * * *$ & 3555 & 20.09 & $0.60^{\mathrm{NS}}$ \\
\hline 4. & Chitradurga & 102681 & 7.58 & $4.13 * * *$ & 195617 & 5.13 & $1.31^{\mathrm{NS}}$ & 2006 & -32.25 & $-2.71 * * *$ \\
\hline 5. & Bellary & 99131 & 7.32 & $6.20 * * *$ & 198750 & 5.21 & $4.30 * * *$ & 2124 & -28.25 & $-1.79 * * *$ \\
\hline 6. & Bijapur & 78640 & 5.81 & $1.69^{\mathrm{NS}}$ & 285862 & 7.49 & $1.52^{\mathrm{NS}}$ & 3827 & 29.29 & $-0.17^{\mathrm{NS}}$ \\
\hline 7. & Bagalkot & 75301 & 5.56 & $5.65 * * *$ & 252074 & 6.60 & $6.52 * * *$ & 3507 & 18.48 & $0.82^{\mathrm{NS}}$ \\
\hline 8. & Hassan & 68454 & 5.05 & $15.82 * * *$ & 198516 & 5.20 & $16.24 * * *$ & 3063 & 3.48 & $0.36^{\mathrm{NS}}$ \\
\hline 9. & Shivamogga & 65994 & 4.87 & $9.38 * * *$ & 250341 & 6.56 & $10.30 * * *$ & 3990 & 34.79 & $0.84^{\mathrm{NS}}$ \\
\hline 10. & Chikballapur & 62533 & 4.62 & $13.72 * * *$ & 167941 & 4.40 & $16.37 * * *$ & 2826 & -4.54 & $2.33^{\mathrm{NS}}$ \\
\hline 11. & Koppal@ & 58958 & 4.35 & $13.49 * * *$ & 2212 & 0.06 & $11.82 * * *$ & 2954 & -0.20 & $-1.33^{\mathrm{NS}}$ \\
\hline 12. & Gadag@ & 54570 & 4.03 & $10.19 * * *$ & 115281 & 3.02 & $8.24 * *$ & 2182 & -26.29 & $-1.77^{\mathrm{NS}}$ \\
\hline 13. & Dharwad & 39662 & 2.93 & $-0.22^{\mathrm{NS}}$ & 90451 & 2.37 & $-1.27^{\mathrm{NS}}$ & 2388 & -19.34 & $-0.86^{\mathrm{NS}}$ \\
\hline 14. & Mysuru & 38211 & 2.82 & $3.69 * * *$ & 102486 & 2.69 & $3.59 * * *$ & 2823 & -4.64 & $-0.10^{\mathrm{NS}}$ \\
\hline 15. & Chamrajnagar@ & 37303 & 2.75 & $9.19 * * *$ & 115715 & 3.03 & $10.37 * * *$ & 3271 & 10.51 & $1.08^{\mathrm{NS}}$ \\
\hline 16. & Tumkur & 25537 & 1.89 & $11.26 * * *$ & 57852 & 1.52 & $10.20 * * *$ & 2385 & -19.45 & $-0.95^{\mathrm{NS}}$ \\
\hline 17. & Chikkamagaluru & 23509 & 1.74 & $22.85 * * *$ & 57982 & 1.52 & $22.49 * * *$ & 2564 & -13.40 & $-0.25^{\mathrm{NS}}$ \\
\hline 18. & Others & 39197 & 2.89 & $2.24 * * *$ & 288420 & 7.56 & $2.88 * * *$ & 3191 & 7.79 & $2.94 * * *$ \\
\hline & State overall & 1354424 & 100.00 & $8.02 * * *$ & 3816610.7 & 100.00 & $7.76^{* * *}$ & 2960 & 100.00 & $-0.25^{\mathrm{NS}}$ \\
\hline
\end{tabular}

Note $\quad: * * * * *$ and ${ }^{\mathrm{NS}}$ indicates significance at one per cent, five per cent and non-significant, respectively.

CAGR for Davanagere, Haveri, Koppal, Gadag and Chamarajanagr districts were calculated for the period from 1998 to 2014, i.e., from the year of reorganisation of districts 
Table.2 Price spread in marketing of maize in channel-I

\begin{tabular}{|c|c|c|c|}
\hline & & & (Rs./qtl.) \\
\hline Sl. No. & Particulars & Value & $\%$ \\
\hline 1. & Farmers participated (no.) & 40 & 66.66 \\
\hline 2. & Quantity sold (\%) & & 62.5 \\
\hline 3. & Net price received by the farmer & 1100 & \\
\hline 4. & Village trader & & \\
\hline a. & Packing, loading, unloading & 23 & 10.82 \\
\hline b. & Transportation & 25 & 11.76 \\
\hline c. & Miscellaneous expenses & 15 & 7.06 \\
\hline d. & Sub total & 63 & 29.65 \\
\hline e. & Profit margin & 15 & 7.06 \\
\hline f. & Village trader sale price & 1178 & \\
\hline 5. & Commission agent cum wholesaler & & \\
\hline a. & Packing, loading, unloading & 20 & 9.41 \\
\hline b. & Transportation & 15 & 7.06 \\
\hline c. & Miscellaneous expenses & 20 & 9.41 \\
\hline d. & Sub total & 55 & 25.88 \\
\hline e. & Wholesaler's margin & 20 & 9.41 \\
\hline f. & Wholesaler's sale price & 1253 & \\
\hline 6. & Retailer & & \\
\hline a. & Packing, loading, unloading & 20 & 9.41 \\
\hline b. & Transportation & & \\
\hline c. & Shop rent & 19.5 & 9.18 \\
\hline d. & Sub total & 39.5 & 18.59 \\
\hline e. & Retailer's margin & 20 & 9.41 \\
\hline f. & Consumer's purchase / Retailer's sale price & 1313 & \\
\hline 7. & Total marketing cost & 157.5 & 74.12 \\
\hline 8. & Profit margin of intermediaries & 55 & 25.88 \\
\hline 9. & Price spread & 212.5 & 100 \\
\hline 10. & Producer's share in consumer's rupees $(\%)$ & 83.78 & \\
\hline
\end{tabular}

Channel I: Producer $\rightarrow$ Villagetrader $\rightarrow$ wholesaler cum commission agent $\rightarrow$ Retaile $\rightarrow$ Consumer 
Table.3 Price spread in marketing of maize in channel-II

\begin{tabular}{|c|c|c|c|}
\hline Sl. No. & Particulars & Value & $\%$ \\
\hline 1. & Farmers participated (no.) & 20 & 33.33 \\
\hline 2. & Quantity sold (\%) & & 23.40 \\
\hline 3. & Expenses incurred by the farmer & & \\
\hline a. & Packing, loading, unloading & 23 & 13.02 \\
\hline b. & Transportation & 10 & 5.66 \\
\hline c. & Personal expenses & 15 & 8.49 \\
\hline d. & Sub total & 48 & 27.16 \\
\hline e. & Producer's sale price & 1200 & \\
\hline f. & Net price received by the farmer & 1152 & \\
\hline 4. & Commission agent cum wholesaler & & \\
\hline a. & Packing, loading, unloading & 20 & 11.32 \\
\hline b. & Transportation & 15 & 8.49 \\
\hline c. & Miscellaneous expenses & 20 & 11.32 \\
\hline d. & Sub total & 55 & 31.13 \\
\hline e. & Wholesaler's margin & 15 & 8.49 \\
\hline f. & Wholesaler's sale price & 1270 & \\
\hline 5. & Retailer & & \\
\hline a. & Packing, loading, unloading & 20 & 11.32 \\
\hline b. & Transportation & & \\
\hline c. & Shop rent & 19.2 & 10.87 \\
\hline d. & Sub total & 39.2 & 22.18 \\
\hline e. & Retailer's margin & 19.5 & 11.04 \\
\hline f. & Consumer's purchase / Retailer's sale price & 1330 & \\
\hline 6. & Total marketing cost & 142.2 & 80.48 \\
\hline 7. & Profit margin of intermediaries & 34.5 & 19.52 \\
\hline 8. & Price spread & 176.7 & 100 \\
\hline 9. & Producer's share in consumer's rupees (\%) & 86.62 & \\
\hline
\end{tabular}

Channel II: Producer $\rightarrow$ wholesaler cum commission agent $\rightarrow$ Retailer $\rightarrow$ Consumer

As regards the quantity of maize marketed, more than 85 per cent (Channel-I: $62.5 \%$ and Channel-II: $23.4 \%$ ) of the produce was sold through these two channels and hence details on per quintal basis marketing cost incurred, profit margin realised, total marketing margin (Price spread) and Producer's Share in Consumer Rupee (PSCR) were worked out and are presented in Table 2.

The total marketing costs and profit margins of all the intermediaries constitute the total marketing margin. The marketing margin was found to be higher in the case of Channel-I than in Channel-II. In other words the total price spread was more in the case of Channel-I (Rs.212.5/q) than in Channel-II (Rs.176.7/q). The lower price spread in the case of Channel-II was due to absence of one market intermediary i.e., Village trader. Hence farmers realised relatively higher share in consumer rupee when they marketed their produce through Channel-II (86.62\%) than Channel-I (83.78\%).

Thus compared to many other farm commodities, the share of farmers in the final 
consumer's rupees was more, as this is handled in large quantity and used in industries like manufacturing of animal feed, etc. However, still in order to increase producer share in final price, contract farming with processing industries would be a viable option as it can minimise the intermediaries in maize marketing, and may have strong influence on price stabilisation. Similarly, organising maize producers organisations would increase their bargaining power not only in maize marketing but also help realise benefit in procuring their needed inputs. Further, need based construction and popularising usage of rural godowns in major growing areas for storage of produce would also help farmers in reaping greater benefits from maize cultivation. In addition, there exists more scope for primary processing of maize at village level so that farmers dependency on cattle feed from market would decreases cattle feed cost.

In the case of channel-I, the share of marketing cost and profit margins of various intermediaries was 75 per cent 25 per cent, while the respective figures for channel-II were 80 per cent and 20 per cent. The Producer's share in consumer's rupees in channel -II was relatively more $(86.6 \%)$ compared to channel -I (83.7\%), hence, Channel-I found to be relatively more efficient than Channel-II.

Maize production in the state during the study period from 1990-2014 increased at rate of 7.76 per cent per annum, due to significant growth rate of 8.02 per cent per annum in area under Maize, but the maize productivity $(-0.25 \%)$ showed decreasing growth rate. Of the four marketing channels observed in the study area, more than 85 per cent (Channel-I: $62.5 \%$ and Channel-II: $23.4 \%$ ) of the produce was sold though channel - I and channel-II. Due to absence of village trader in channel II (Through APMC), Producer's share in consumer's rupees was more $(86.6 \%)$ compared channel -I $(83.7 \%)$.

\section{References}

Arti Thakur, Chandan Kumar Rai., 2017, Growth rate of Area, Production and productivity of sugarcane crop in Uttar Pradesh. Research J. Agric. Sci., 8(2): 423-425.

Bhat Anil, Jyoti Kachroo and Dileep Kachroo., 2011, Economic Appraisal of Kinnow Production and its Marketing under NorthWestern Himalayan Region of Jammu Agricultural Economics Research Review, 24: 283-290.

Manjeet Kaur, Sekhon, M. K. and Anuradha Joshi, 2014, Marketing pattern and price spread of guava in Punjab. Ind. J Econ Dev., 10 (1): 77-85.

Naveen, B., Jayaram, M.S., Dhananjaya Swamy, P.S., Ramesh, G.B. and Raghavendra, D.V., 2015, Marketing channels and price spread of banana in Chikkaballapur district of Karnataka. International Research Journal of Agricultural Economics and Statistics., 6(1): 18-22.

Sharma A.,2013, Trends of Area, Production and Productivity of Food grain in the North Eastern States of India. Indian J. Agric. 2013; 47(4):341-346.

Venkataramana Reddy, V., Venkataramana, M.N., Dhananjaya Swamy, P.S. AND Harish Kumar, H.V., 2015, Economic analysis of marketing channels and efficiency of marketing of finger millet (Ragi) in Karnataka. International Research Journal of Agricultural Economics and Statistics.6 (1): 27-31.

\section{How to cite this article:}

Murulidhar M. Venkannanvara, G. M. Gaddi and Gracy, C. P. 2019. Growth Performance and Marketing of Maize in Karnataka, India. Int.J.Curr.Microbiol.App.Sci. 8(10): 380-387. doi: https://doi.org/10.20546/ijcmas.2019.810.039 